\title{
KAJIAN EFISIENSI ALOKASI PENGGUNAAN INPUT PADA USAHA TERNAK AYAM RAS PETELUR
}

\author{
Kustiawati Ningsih \\ Program Studi Agribisnis, Universitas Islam Madura \\ Kompleks Ponpes Miftahul Ulum Bettet, Pamekasan, Madura, Kode Pos 69351, Indonesia \\ E-mail : ningsihkustiawati@yahoo.com
}

\begin{abstract}
The research wasconducted inJune-July 2013 at Bettet Village Pamekasan City Subdistrict Pamekasan Regency. The research objectivewas to determine the allocation efficiency of input use on breeding laying hens. Secondary and primary data were obtained through interview and observation methods. Descriptive analysis with applying the Cobb-Douglas production function and testing Efficiency Value Price for Input Use (Factor) is used to analyze the data. Results showed that the model of Cobb Douglas production function breeding laying hens at Bettet Village Pamekasan City Subdistrict Pamekasan Regenc yis quite good. This can be seen in the value of $R^{2}=0.9585$, meaning that the independent variable $(X 1 \mathrm{~s} / \mathrm{dX6})$ in the modelis able to explain the relationship with the dependent variable (production) of $95.85 \%$, while the remaining $4.15 \%$ is explained by other variables not in the study. In addition, the results of the Cobb Douglas production function model breeding laying hens at Bettet Village have calculated $F$ value $=527.485>F$ table $=2.599$ with $\alpha$ $=0.05$ and degrees of freedom $d f(6,20)$, meaning that the independent variables $(X 1$ s/dX6) together in a model that explains the relationship of the dependent variable (production) significantly. Assessment results for the efficiency of use of each input prices (factor) indicates that the allocation of the inputs on breeding laying hens at Bettet Village Pamekasan City Subdistrict Pamekasan Regency still not efficient. It can be seen from the $t$ value of each input is greater thanttable with $\alpha=0.05$ and 19 degrees of freedom $(d f=19)$.
\end{abstract}

Keywords : Allocative Efficiency,Production Function, Cobb-Douglas, Breeding Laying Hens

Abstrak: Penelitian ini dilakukan pada Bulan Juni-Juli 2013 di Desa Bettet
Kecamatan Kota Pamekasan Pamekasan Kabupaten Pamekasan. Tujuan penelitian
adalah untuk mengetahui efisiensi alokasi penggunaan input pada usaha ternak ayam
petelur. Data primer dan sekunder diperoleh melalui wawancara dan metode
observasi.Analisis deskriptif dengan penerapan fungsi produksi Cobb-Douglas dan
pengujian Nilai Efisiensi Harga untuk Penggunaan Setiap Input (Faktor Produksi)
digunakan untuk menganalisis data. Hasil penelitian menunjukkan bahwaModel
fungsi produksi Cobb Douglas usaha ternak ayam petelur di Desa Bettet Kecamatan
Kota Pamekasan Kabupaten Pamekasan adalah model yang cukup baik. Hal ini dapat
dilihat pada nilai R2=0,9585, artinya variabel independent (X1 s/d X6) dalam model
mampu menjelaskan hubungannya dengan variabel dependent (produksi) sebesar
95,85\%, sisanya sebesar $4,15 \%$ dijelaskan oleh variabel lainnya yang tidak ada dalam
penelitian. Selain itu, hasil dari Model fungsi produksi Cobb Douglas peternakan
ayam petelur di Desa Bettet memiliki nilai F hitung = 527,485 $>$ F tabel = 2,599
dengan a = 0,05 dan derajat kebebasan df $(6,20)$, artinya variabel independen (X1 s/d
X6) secara bersama-sama dalam model mampu menjelaskan hubungannya terhadap
variabel dependen (produksi) secara signifikan. Hasil penilaian efisiensi harga untuk
Penggunaan Setiap Input (Faktor Produksi) menunjukkan bahwa alokasi penggunaan 
input pada usaha ternak ayam petelur di Desa Bettet Kecamatan Kota Pamekasan masih belum efisien. Hal ini dapat dilihat dari nilai t hitung masing-masing input yang lebih besar dari $t$ tabel dengan $\alpha=0,05$ dan derajat bebas $19(\mathrm{df}=19)$.

Kata Kunci : Efisiensi Alokasi, Fungsi Produksi, Cobb-Douglas, Usaha Ternak Ayam Petelur

\section{PENDAHULUAN}

Subsektor pertanian yang berperan penting dalam pemenuhan kebutuhan protein hewani adalah subsektor peternakan. Sampai saat ini, kebutuhan masyarakat akan hasil ternak seperti daging, susu dan telur terus meningkat. Hal ini sejalan dengan meningkatnya jumlah penduduk, tingkat pendidikan, kesadaran masyarakat akan gizi dan peranan zat-zat makanan khususnya protein bagi kehidupan, serta meningkatnya kemampuan masyarakat untuk memanfaatkan hasil ternak, sehingga perkembangan sektor peternakan dapat memberikan dampak positif bagi masyarakat untuk peningkatan perbaikan gizi dan dapat memberikan dampak positif bagi pelaku ternak yaitu meningkatnya kesejahteraan pelaku ternak.

Salah satu jenis ternak unggas yang cukup berkembang di Jawa Timur adalah ayam petelur. Data statistik peternakan dan kesehatan hewan (2011) menunjukkan bahwa populasi ayam ras petelur di Jawa Timur ratarata $30 \%$ dari total keseluruhan populasi ayam ras petelur di Indonesia. Sedangkan berdasarkan data Dinas Peternakan Provinsi Jawa Timur (2012) menunjukkan bahwa populasi ayam ras petelur di Jawa Timur mulai tahun 2008 sampai 2011 terus mengalami kenaikan dengan jumlah ternak ayam ras petelur berturut-turut 20.886.094 ekor, 21.396.786 ekor, 21.959.505 ekor dan 37.035.241 ekor. Harga telur yang relatif murah dan mudah terjangkau oleh lapisan masyarakat menyebabkan usaha ternak ayam petelur adalah usaha yang dapat menghasilkan perputaran modal yang cepat. Oleh karena itu, usaha ternak ayam petelur merupakan salah satu peluang usaha yang besar kemungkinannya dapat memberikan keuntungan yang sangat besar.

Namun berdasarkan kondisi di lapangan, usaha ternak ayam petelur di Desa Bettet menghadapi struktur biaya produksi yang tinggi dalam melakukan kegiatan usahanya. Selain itu, usaha ternak ayam petelur dikenal sebagai usaha yang intensif modal sedangkan di pihak lain usaha ternak ayam petelurdi Desa Bettet ini diusahakan oleh peternak kecil yang memiliki modal dan pengetahuan terbatas serta penggunaan teknologi yang sederhana, sehingga keadaan ini akan mempengaruhi pada efisiensi pemakaian masukan (faktor produksi). Atas dasar uraian di atas, peneliti memandang menarik untuk meneliti efisiensi alokasi penggunaan inputpadausaha ternak ayam petelur.

\section{METODE PENELITIAN}

\section{Tempat dan Waktu Penelitian}

Penelitian ini dilaksanakan di Desa Bettet Kecamatan Kota Pamekasan Kabupaten Pamekasan. Hal ini disebabkan karena di desa tersebut terdapat peternakan ayam petelur terbanyak diantara daerah-daerah lainnya, disamping itu Desa Bettet juga merupakan sentra produksi ayam petelur. Penentuan lokasi dilakukan secara purposive atau sengaja. Penelitian ini dilaksanakan pada Bulan JuniJuli 2013.

\section{Metode Penentuan Sampel}

Populasi dalam penelitian ini adalah semua pelaku usaha peternakan ayam ras petelur di Desa Bettet Kecamatan Kota Pamekasan Kabupaten Pamekasan. Adapun jumlah keseluruhan pelaku usaha ternak ayam ras petelursebanyak $20 \mathrm{KK}$ peternak kecil. Oleh karena penelitian ini menggunakan metode sensus, maka yang menjadi objekpenelitian adalah seluruh pelaku usaha ternak ayam ras petelur yang ada di Desa Bettet Kecamatan Kota Pamekasan Kabupaten Pamekasan.

\section{Metode Analisis Data}

Dalam penelitian ini, analisis data yang digunakan adalah analisis kualitatif dan kuantitatif. Analisis data kualitatif 
dipergunakan untuk mendeskripsikan tentang gambaran umum responden. Sedangkan analisis kuantitatif dipergunakan untuk mengetahui efisiensi alokasi penggunaan input usaha ternak ayam ras petelur. Penelitian ini bertujuan untuk mengetahui efisiensi alokasi penggunaan input pada usaha ternak ayam ras petelur, alat analisis yang digunakan adalah model pengukuran efisiensi produksi yang diestimasi dengan fungsi produksi CobbDouglas. Ketentuan dasar didalam keputusan penggunaan model adalah bahwa kegiatan usaha ternak ayam ras petelur diasumsikan mengikuti hukum pertambahan hasil yang semakin menurun.

\section{Model Pengukuran Efisiensi Produksi}

Seperti yang telah disampaikan sebelumnya, bahwa model pengukuran efisiensi produksi diestimasi dengan fungsi produksi CobbDouglas.

Secara umum fungsi produksi Cobb Douglas adalah

$\mathrm{Y}=\mathrm{A} \mathrm{L} \mathrm{L}^{\mathrm{a}} \mathrm{b}^{\mathrm{b}}$

Dimana :

$\mathrm{Y} \quad=$ total output

$\mathrm{L}$ dan $\mathrm{K} \quad=$ input labor dan kapital

$\mathrm{A}, \mathrm{a}, \mathrm{b} \quad=$ parameter tetap bernilai positif

e $\quad=$ error

asumsi $\quad: 0<\mathrm{a} \leq 1 ; 0<\mathrm{b} \leq 1 ; \mathrm{a}+\mathrm{b} \leq 1$

Dalam penelitian ini, model umum yang digunakan adalah :

$\mathrm{Y}=\mathrm{a}_{0} \mathrm{X} 1^{\mathrm{b} 1} \times 2^{\mathrm{b} 2} \times 3^{\mathrm{b} 3} \times 4^{\mathrm{b} 4} \times 5^{\mathrm{b} 5} \times 6^{\mathrm{b} 6} \mathrm{e}^{\mathrm{u}}$

Untuk dapat dianalisis, model di atas diubah ke dalam bentuk logaritma berganda menjadi model persamaan linier seperti :

$\operatorname{Ln} \mathrm{Y}=\mathrm{a}_{0}+\mathrm{b} 1 \operatorname{Ln} \mathrm{X} 1+\mathrm{b} 2 \operatorname{Ln} \mathrm{X} 2+\mathrm{b} 3 \operatorname{Ln} \mathrm{X} 3$

$+\mathrm{b} 4 \operatorname{Ln} \mathrm{X} 4+\mathrm{b} 5 \operatorname{Ln} \mathrm{X} 5+\mathrm{b} 6 \operatorname{Ln} \mathrm{X} 6+\mathrm{u}$

Dimana :

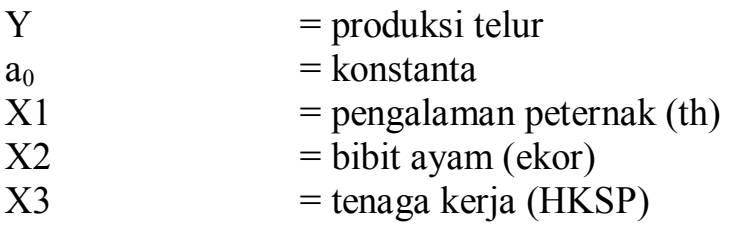

$$
\begin{array}{ll}
\mathrm{X} 4 & =\operatorname{pakan}(\mathrm{Kg}) \\
\mathrm{X} 5 & =\operatorname{vaksin}(\mathrm{gr}) \\
\mathrm{X} 6 & =\operatorname{listrik}(\text { watt }) \\
\mathrm{b} 1, \mathrm{~b} 2, \mathrm{~b} 3, \mathrm{~b} 4, \mathrm{~b} 5, \mathrm{~b} 6 & =\text { parameter peubah input } \\
\mathrm{u} & =\text { error }
\end{array}
$$

Berdasarkan hasil analisis model fungsi produksi di atas, makadapat menghasilkan koefisien regresi pada masing-masing faktor produksi yang digunakan. Sehingga untuk kepentingan uji efisiensi teknis, maka dapat dilihat pada jumlah koefisien regresi atau $\sum \beta_{i}$ dimana jumlah koefisien regresi menunjukkan elastisitas produksi. Adapun ketentuan yang harusdipenuhiadalahsebagai berikut

1. Bila $\sum \beta_{i}>1$ disebut Increasing Return to Scale, Artinya, proporsi penambahan masukan produksi akan menghasilkan tambahan produksi dengan proporsi yang lebih besar dan jika dihubungkan dengan kurva produksi maka berada pada daerah I yaitu daerah irrasional.

2. Bila $\sum \beta_{i}=1$ disebut Constant Return to Scale, artinya, penambahan masukan produksi akan proporsional dengan penambahan produksi yang diperoleh dan jika dihubungkan dengan kurva produksi maka berada pada daerah II yaitu daerah rasional serta memenuhi kriteria efisien secara teknis.

3. Bila $\sum \beta_{i}<1$ disebut Decreasing Return to Scale, artinya, proporsi penambahan masukan produksi melebihi proporsi penambahan produksi dan jika dihubungkan dengan kurva produksi maka berada pada daerah II yaitu daerah rasional.

\section{Pengujian Model Regresi Fungsi Produksi Cobb Douglas}

Untuk melihat ketepatan model regresi dari fungsi produksi yang dipakai, dilakukan uji-F dengan hipotesis statistik sebagai berikut :

$$
\begin{gathered}
H_{0}: \alpha_{1}^{*}=\alpha_{2}^{*}=\cdots=\alpha_{m}^{*}=0 \text { (untuk semua } \mathrm{i} \\
\text { dimana } \mathrm{i}=1,2, \ldots, \mathrm{m} \text { ) }
\end{gathered}
$$

$H_{1}$ : salah satu koefisien regresi atau semua $\left(\alpha_{1}^{*}\right) \neq 0$ 
$\mathrm{F}_{\text {hitung }}$ bisa dicari dengan rumus sebagai berikut (Gujarati, 1995) :

$$
F_{\text {hitung }}=\frac{R^{2} /(k-1)}{\left(1-R^{2}\right) /(n-k)}
$$

Apabila $\quad \mathrm{F}_{\text {hitung }}<\quad \mathrm{F}_{\text {tabel }} \quad$ maka keputusannya adalah menerima $H_{0}$, yang berarti model regresi tidak bisa menjelaskan variasi peubah terikatnya. Dan sebaliknya jika $\mathrm{F}_{\text {hitung }}>$ $\mathrm{F}_{\text {tabel }}$ maka $H_{0}$ ditolak, artinya model tersebut dapat menjelaskan variasi peubah terikatnya. Selain itu juga dilihat dari nilai koefisien determinasi $\left(\mathrm{R}^{2}\right)$, makin mendekati satu makin bagus model tersebut.

\section{Pengujian Pengaruh Masing-masing Peubah Bebas}

Untuk mengetahui faktor-faktor produksi atau input apa saja yang mempengaruhi produksi usaha ternak ayam ras petelur serta bagaimana pengaruh masing-masing peubah bebas terhadap produksi usaha ternak ayam ras petelur dilakukan uji-t dengan hipotesis berikut :

$H_{0}: \alpha_{i}^{*}=0$

$H_{1}: \alpha_{i}^{*} \neq 0$

Menurut Gujarati (1995) t-statistik (thitung) dapat dicari dengan rumus sebagai berikut:

thitung $=\frac{\beta_{i}}{\operatorname{Se} \beta_{i}}$

Dimana

$\beta_{i} \quad=$ koefisien regresi ke-i

$\mathrm{Se} \beta_{i} \quad=$ standard error dari koefisien regresi

Kriteria pengambilan keputusannya adalah jika $\mathrm{t}_{\text {hitung }}<\mathrm{t}_{\text {tabel }}$ maka $\mathrm{H}_{0}$ diterima, artinya peubah bebas ke-i tersebut tidak berpengaruh nyata terhadap produksi. Sebaliknya jika $t_{\text {hitung }}>$ $t_{\text {tabel }}$ maka $\mathrm{H}_{0}$ ditolak, artinya peubah bebas ke-i tersebut berpengaruh nyata terhadap produksi.

Uji Nilai Efisiensi Harga untuk Penggunaan Setiap Input (Faktor Produksi)

Untuk melihat apakah efisiensi harga untuk penggunaan setiap faktor produksi (input) pada usaha ternak ayam ras petelur efisien atau tidak efisien maka pengujian dilakukan dengan uji one sample t test

$\mathrm{H}_{0} \quad: \mathrm{ki}=1$

$\mathrm{H}_{1} \quad: \mathrm{ki} \neq 1$

Untuk menguji apakah hasil perhitungan efisiensi harga untuk penggunaan setiap input atau faktor produksi sama dengan satu atau tidak, maka dilakukan uji t dengan cara :

thitung $=\frac{1-K}{\text { Se } K} \sim$ t tabel $(\alpha / 2 ; n-k)$

Dimana : $\quad \mathrm{K}=$ efisiensi harga faktor Xi; $\mathrm{k}=$ totalitas parameter

Dengan kriteria apabila nilai $-t(\alpha / 2, d f) \leq$ thitung $\leq t(\alpha / 2, d f)$ maka terima $\mathrm{H}_{0}$, berarti efisiensi harga untuk setiap penggunaan input sama dengan 1 dan menunjukkan bahwa faktor produksi telah digunakan secara efisien harga, dan jika thitung $<-t(\alpha / 2, d f)$ atau thitung $>$ $t(\alpha / 2, d f)$ maka tolak $\mathrm{H}_{0}$, efisiensi harga untuk penggunaan setiap input tidak sama dengan 1 dan menunjukkan bahwa penggunaan input tidak mencapai efisiensi harga.

\section{HASIL DAN PEMBAHASAN}

\section{Analisis Faktor- Faktor Produksi Yang Mempengaruhi Produksi Usaha Ternak Ayam Petelur}

Dari hasil analisis fungsi produksi pada usaha ternak ayam petelur di Desa Bettet, diperoleh persamaan regresi sebagai berikut :

$\operatorname{LnY}=1,31+0,12 \operatorname{In} X_{1}+0,37 \operatorname{In} X_{2}+0,14 \operatorname{In} X_{3}+$ $0,11 \operatorname{InX}_{4}+0,12 \operatorname{InX} X_{5}+0,11 X_{6}+u$

Dimana :

$\mathrm{Y} \quad=$ jumlah produksi telur $(\mathrm{Kg})$

$\mathrm{X}_{1} \quad=$ pengalaman peternak (tahun)

$\mathrm{X}_{2} \quad=$ bibit ayam (ekor)

$\mathrm{X}_{3}=$ tenaga kerja (HKSP)

$\mathrm{X}_{4} \quad=$ pakan $(\mathrm{kg})$

$\mathrm{X}_{5}=\operatorname{vaksin}(\mathrm{gr})$

$\mathrm{X}_{6} \quad=$ listrik (watt)

$\mathrm{U} \quad=$ error 
Kustiawati Ningsih: Kajian Efisiensi Alokasi Penggunaan Input ...

Tabel 1. Pendugaan Koefisien Regresi Fungsi Produksi Usaha Ternak Ayam Petelur di DesaBettet Kecamatan Kota PamekasanKabupaten Pamekasan

\begin{tabular}{ccccc}
\hline No & $\begin{array}{c}\text { Variabel } \\
\text { (variable) }\end{array}$ & $\begin{array}{c}\text { Koefisien Regresi } \\
\text { (regression coefficient) }\end{array}$ & $\begin{array}{c}\text { Uji } \mathrm{t}(\alpha=0,05) \text { dan } \mathrm{df}=20 \\
\text { t hitung }(\text { tvalue })\end{array}$ & t tabel \\
\hline 1 & $\mathrm{X}_{1}$ & 0,12 & 2.814 & 2,086 \\
2 & $\mathrm{X}_{2}$ & 0,37 & 7.046 & \\
3 & $\mathrm{X}_{3}$ & 0,14 & 4.241 \\
4 & $\mathrm{X}_{4}$ & 0,11 & 2.255 \\
5 & $\mathrm{X}_{5}$ & 0,12 & 2.669 \\
6 & $\mathrm{X}_{6}$ & 0,11 & 2.398 & \\
\hline
\end{tabular}

Sumber : Data Primer (diolah) 2013

Sehingga jika persamaan regresi di atas ditransformasikan ke dalam fungsi pangkat (bentuk power function) menjadi :

$Y={ }_{e} 1,31 \mathrm{X}_{1}{ }^{0,12} \mathrm{X}_{2}{ }^{0,37} \mathrm{X}_{3}{ }^{0,14} \mathrm{X}_{4}{ }^{0,11} \mathrm{X}_{5}{ }^{0,12} \mathrm{X}_{6}{ }^{0,11}{ }_{e}^{\mathrm{u}}$
$\mathrm{Y}=1,0 X_{1}{ }^{0,12} \mathrm{X}_{2}{ }^{0,37} \mathrm{X}_{3}{ }^{0,14} \mathrm{X}_{4}{ }^{0,11} \mathrm{X}_{5}{ }^{0,12} \mathrm{X}_{6}{ }^{0,11}{ }_{e} \mathrm{u}$

Model dalam persamaan regresi tersebut harus diuji signifikansinya dengan uji $\mathrm{t}$ dimana $\alpha=0,05$ dan derajat kebebasan $20(\mathrm{df}=20)$ sehingga diperoleh koefisien regresi sebagaimana terangkum dalam Tabel 1.

Berdasarkan hasil analisis pada Tabel 1. diperoleh koefisien regresi dimana arti dari masing-masing koefisien regresi tersebut adalah :

Variabel pengalaman peternak $\left(\mathrm{X}_{1}\right)=0,12$, berarti hubungan antara jumlah produksi dengan pengalaman peternak adalah positif. Artinya peternak yang memiliki pengalaman cukup lama akan mempengaruhi jumlah produksi telur. Dari hasil uji signifikansi diperoteh hasil $\mathrm{t}$ hitung $=2,814>\mathrm{t}$ tabel $=$ 2,086, sehingga dapat diartikan bahwa variabel $\mathrm{X} 1$ (pengalaman peternak) berpengaruh signifikan terhadap jumlah produksi. Pengalaman peternak memiliki pengaruh positif dan nyata, artinya makin bertambahnya pengalaman peternak dalam berusaha ternak ayam petelur akan cenderung meningkatkan jumlah produksi. Hal ini disebabkan karena pengalaman beternak sangat bervariasi diantara peternak, mengingat seluruh peternak memiliki pengalaman melakukan usaha ternak ayam petelur minimal 5 tahun sampai 10 tahun, yaitu merupakan waktu yang lama dalam menimba pengalaman berusaha ternak ayam petelur, sehingga sikap atau perilaku dalam melaksanakan usaha ternak ayam petelur berbeda diantara peternak. Karenanya faktor pengalaman dapat menjelaskan sikap maupun perilaku peternak dalam berusaha ternak ayam petelur di daerah penelitian. Kenyataan ini sesuai dengan pendapat Saefudin (1988) dalam Soekartawi (1993) yang menyatakan bahwa diantara beberapa faktor yang mempengaruhi pembentukan sikap seseorang adalah pengalaman pribadinya. Dengan pengalaman yang matang, tidak jarang peternak dapat meramalkan untuk masa yang akan datang, yang biasanya dijadikan dasar pertimbangan dalam pengambilan keputusan untuk berproduksi atau tidak.Dalam usaha ternak ayam petelur, pengalaman peternak yang dimaksud adalah berkenaan dengan pengalamannya dalam melaksanakan kegiatan usaha ternak ayam petelur, dan tampaknya kondisi peternak setempat di daerah penelitian mendukung pendapat ini yakni bahwa di dalam pengambilan keputusan berusaha ternak ayam petelur lebih dipengaruhi oleh keadaan lingkungan dan pengalamannya dalam berusaha ternak ayam petelur.

Variabel bibit $(\mathrm{X} 2)=0,37$, berarti hubungan antara jumlah produksi dengan bibit adalah positif. Jika penggunaan bibit naik $1 \%$, maka jumlah produksi akan naik sebesar 0,37\%. Dari hasil uji signifikansi diperoleh hasil t hitung $=$ $7,046>\mathrm{t}$ tabel $=2,086$, sehingga dapat diartikan bahwa variabel X2 (bibit) berpengaruh signifikan terhadap jumlah produksi. Bibit memiliki pengaruh positif dan nyata, artinya semakin banyak bibit yang digunakan, maka semakin meningkatkan jumlah produksi.

Variabel tenaga kerja $(\mathrm{X} 3)=0,14$, berarti hubungan antara jumlah produksi dengan tenaga kerja adalah positif. Jika 
penggunaan tenaga kerja naik $1 \%$, maka jumlah produksi akan naik sebesar $0,14 \%$. Dari hasil uji signifikansi diperoleh hasil t hitung $=4,241$ $>\mathrm{t}$ tabel $=2,086$, sehingga dapat diartikan bahwa variabel X3 (tenaga kerja) berpengaruh signifikan terhadap jumlah produksi, tenaga kerja memiliki pengaruh positif dan nyata, artinya semakin banyak tenaga kerja yang digunakan maka cenderung semakin meningkatkan produksi.

Variabel pakan $(\mathrm{X} 4)=0,11$, berarti hubungan antara jumlah produksi dengan pakan adalah positif. Jika penggunaan pakan naik $1 \%$, maka jumlah produksi akan naik sebesar $0,11 \%$. Dari hasil uji signifikansi diperoleh hasil $\mathrm{t}$ hitung $=2,255>\mathrm{t}$ tabel $=2,086$, sehingga dapat diartikan bahwa variabel X4 (pakan) berpengaruh signifikan terhadap jumlah produksi. Variabel pakan memiliki pengaruh positif dan nyata, artinya semakin banyak pakan yang digunakan, maka semakin meningkatkan jumlah produksi.

Variabel vaksin $(X 5)=0,12$, berarti hubungan antara jumlah produksi dengan penggunaan vaksin adalah positif. Jika penggunaan vaksin naik $1 \%$, maka jumlah produksi akan naik sebesar $0,12 \%$. Dari hasil uji signifikansi diperoleh hasil t hitung $=2,669$ $>\mathrm{t}$ tabel $=2,086$, sehingga dapat diartikan bahwa variabel X5 (vaksin) berpengaruh signifikan terhadap jumlah produksi. Variabel vaksin memiliki pengaruh positif dan nyata, artinya semakin banyak vaksin yang digunakan maka produksi cenderung semakin meningkat.

Variabel listrik $(\mathrm{X} 6)=0,11$, berarti hubungan antara jumlah produksi dengan penggunaan listrik adalah positif. Jika penggunaan listrik naik $1 \%$, maka jumlah produksi akan naik sebesar $0,11 \%$. Dari hasil uji signifikansi diperoleh hasil t hitung $=2,398$ $>\mathrm{t}$ tabel $=2,086$, sehingga dapat diartikan bahwa variabel X6 (listrik) berpengaruh signifikan terhadap jumlah produksi. Variabel listrik memiliki pengaruh positif dan nyata, artinya semakin terkontrol listrik yang digunakan maka cenderung semakin meningkatkan produksi.

Model fungsi produksi Cobb Douglas usaha ternak ayam petelur di Desa Bettet Kecamatan Kota Pamekasan Kabupaten Pamekasan adalah model yang cukup baik. Hal ini dapat dilihat pada nilai $\mathrm{R} 2=0,9585$, artinya variabel independent (X1 s/d X6) dalam model mampu menjelaskan hubungannya dengan variabel dependent (produksi) sebesar 95,85\%, sisanya sebesar $4,15 \%$ dijelaskan oleh variabel lainnya yang tidak ada dalam penelitian. Selain itu, untuk melihat baik tidaknya suatu model dapat dilihat dari nilai $\mathrm{F}$ hitung. Hasil dari Model fungsi produksi Cobb Douglas peternakan ayam petelur di Desa Bettet memiliki nilai $\mathrm{F}$ hitung $=527,485>\mathrm{F}$ tabel $=$ 2,599 dengan $\mathrm{a}=0,05$ dan derajat kebebasan $\mathrm{df}$ $(6,20)$, artinya variabel independen (X1 s/d X6) secara bersama-sama dalam model mampu menjelaskan hubungannya terhadap variabel dependen (produksi) secara signifikan.

\section{Analisis Efisiensi Penggunaan Input (Efisiensi Alokasi Sumber daya) Pada Usaha Ternak Ayam Petelur}

Pengujian efisiensi alokatif (efisiensi alokasi sumberdaya) didasarkan pada asumsi pasar persaingan sempurna, yaitu harga produk (output) dan input diasumsikan sama untuk setiap peternak. Pengujian hipotesis ini dimaksudkan untuk mengetahui apakah rata-rata peternak telah mengalokasikan inputnya secara efisien. Dalam artian bahwa petemak menggunakan sumberdayanya secara optimum pada tingkat keuntungan maksimum. Efisiensi alokatif penggunaan input akan tercapai jika slope dari fungsi produksi sama dengan rasio harga inputoutput, w/p (harga riil) atau nilai produk marjinal dari penggunaan input sama dengan biaya opportunitasnya (w). Perlu diingat bahwa teknik yang dipakai dalam pengujian hipotesis untuk menganalisis efisiensi alokatif pemakaian input ini bukan secara individual, tetapi secara rata-rata atau keseluruhan peternak.

Analisis efisiensi penggunaan input (efisiensi alokatif) didasarkan pada koefisien regresi yang dihasilkan pada model fungsi produksi. Untuk lebih jelasnya, penghitungan efisiensi harga untuk penggunaan masingmasing input pada usaha ternak ayam petelur dapat disarikan dalam Tabel 2.

Tabel 2. menunjukkan bahwa alokasi penggunaan input pada usaha ternak ayam petelur di Desa Bettet Kecamatan Kota Pamekasan tidak efisien. 
Kustiawati Ningsih: Kajian Efisiensi Alokasi Penggunaan Input ...

Tabel 2. Hasil besarnya perhitungan nilai efisiensi harga untuk penggunaan setiap faktor Produksi pada Usaha ternak ayam petelur di Desa Bettet Kec. Kota Pamekasan Kabupaten Pamekasan

\begin{tabular}{lllll}
\hline No & $\begin{array}{l}\text { Variabel } \\
\text { (Input) }\end{array}$ & Nilai ki* & t hitung & t tabel \\
\hline 1 & X2 (bibit) & 0,5912 & -24.591 & $-1,960$ \\
2 & X3 (tenaga kerja) & 0,1080 & -534.336 & $-1,960$ \\
3 & X4 (pakan) & 379,2693 & 49.180 & 1.960 \\
4 & X5(vaksin) & 2,0279 & -154.415 & $-1,960$ \\
5 & X6 (listrik) & 0,2821 & -25.351 & $-1,960$ \\
\hline
\end{tabular}

Sumber : Data Primer (diolah) 2013

Hal ini dapat dilihat dari nilai t hitung masingmasing input yang lebih besar dari $t$ tabel dengan $\alpha=0,05$ dan derajat bebas 19 (df = 19). Sehingga sesuai uji hipotesis, maka dapat disimpulkan H0ditolak dan H1 diterima yaitu nilai $\mathrm{ki}^{*} \neq 1$ yang berarti bahwa efisiensi harga untuk penggunaan setiap input usaha ternak ayam petelur di Desa Bettet Kecamatan Kota Pamekasan tidak efisien.Hal ini mengindikasikan terjadinya pemakaian input berlebih pada usaha ternak ayam petelur, sehingga biaya produksi menjadi tinggi dan menurunkan nilai produksi serta menurunkan pendapatan peternak ayam petelur. Hal ini menunjukkan bahwa peternak ayam petelur masih belum mampu mengikuti anjuran pemakaian bibit, tenaga kerja, pakan, vaksin dan listrik dari Penyuluh Lapangan Dinas Peternakan Kabupaten Pamekasan sehingga penggunaan bibit, tenaga kerja, pakan, vaksin dan listrik belum efisien. Sehingga dapat disimpulkan bahwa alokasi input produksi dalam usaha ternak ayam petelur belum sepenuhnya efisien secara alokatif.

Selain itu, dari hasil analisis terhadap fungsi produksi usaha ternak ayam petelur di Desa Bettet Kecamatan Kota Pamekasan secara teknis persentase tambahan input melebihi persentase tambahan output atau tambahan sejumlah input tidak diimbangi secara proporsional oleh tambahan output yang diperoleh. Penjelasan ini bertitik tolak dari jumlah koefisien garis regresi atau $\sum b_{i}=0,859$. Hal ini menunjukkan bahwa kondisi skala usaha ternak ayam petelur di Desa Bettet Kecamatan Kota Pamekasanberada pada kondisi Decreasing Return to Scale (DRTS). Selain itu hal ini berarti bahwa secara teknis, para peternak menunjukkan perilaku yang tidak efisien, dan jika dikaitkan ke dalam bentuk skala usaha menurut Soekartawi (1994) maka usaha ternak ayam petelur berada di daerah II dengan $0<$ Ep $<1$.

Berdasarkan hasil analisis uji efisiensi harga menunjukkan bahwa kegiatan usaha ternak ayam petelur di DesaBettet Kecamatan Kota Pamekasan tidak dapat memenuhi kriteria efisiensi teknis dan efisiensi harga.Dengan demikian, bila dikaitkan pada prinsip dasar efisiensi dalam bentuk skala usaha, maka kegiatan usaha ternak ayam petelur berada pada daerah II dengan elastisitas produksi $0<\mathrm{Ep}<$ 1. Oleh karena usaha ternak ayam petelur memiliki nilai elastisitas produksi kurang dari satu, maka hal ini menunjukkan bahwa secara teknis usaha ternak ayam petelur masih belum efisien dimana usaha ternak ayam petelur harus melakukan realokasi penggunaan inputnya sehingga mencapai tingkat produksi optimal.

Secara teknis, peternak ayam petelur di Desa Bettet Kecamatan Kota Pamekasan tidak mampu memenuhi kriteria efisiensi dan tidak mampu memenuhi kriteria efisiensi harga oleh karena jumlah penggunaan input produksi ternyata belum maksimaldalam artianproporsi penambahan input produksi melebihi proporsi penambahan produksi. Secara teknis, seyogyanya peternak melakukan realokasi penggunaan inputnya.Hal ini sejalan dengan pendapat Setiawan (2007) yaitu kurangnya pengetahuan tentang teknologi peternakan yang tepat guna akan menyebabkan inefisiensi teknis. Sehingga dari uraian di atas, dapat disimpulkan usaha ternak ayam petelur masih belum mencapai efisiensi ekonomi. Hal ini dibuktikan tidak tercapainya efisiensi teknis dan efisiensi harga (efisiensi alokatif) pada usaha ternak ayam petelur. Hal ini sejalan dengan pendapat yang dikemukakan oleh Soekartawi (1994) yaitu efisiensi ekonomi akan tercapai apabila efisiensi teknis dan efisiensi harga (efisiensi alokatif) tercapai. 


\section{KESIMPULAN DAN SARAN}

\section{Kesimpulan}

Berdasarkan hasil analisis terhadap usaha ternak ayam petelur di Desa Bettet, maka dapat disimpulkan sebagaiberikut:

Faktor - faktor / variabel yang berpengaruh nyata terhadap produksi adalah pengalaman peternak, bibit ayam (DOC), pakan, tenaga kerja, vaksin dan listrik.

Rata-rata tingkat efisiensi teknis yang dicapai peternak ayam petelur sudah berada pada daerah II dengan elastisitas produksi $0<$ Ep $<1$. Oleh karena usaha ternak ayam petelur memiliki nilai elastisitas produksi kurang dari satu, maka hal ini menunjukkan bahwa secara teknis usaha ternak ayam petelur masih belum efisien dimana usaha ternak ayam petelur harus melakukan realokasi penggunaan inputnya sehingga dapat mencapai tingkat produksi yang optimal. Secara teknis, peternak ayam petelur di Desa Bettet Kecamatan Kota Pamekasan tidak mampu memenuhi kriteria efisiensi dan tidak mampu memenuhi kriteria efisiensi harga. Hal ini terbukti bahwa jumlah penggunaan input produksi ternyata tidakmaksimaldalam artianproporsi penambahan input produksi melebihi proporsi penambahan produksi.

\section{Saran}

Berkenaan dengan upaya peningkatan efisiensi dan produksi dari hasil usaha peternakan ayam petelur di Desa Bettet, dan mengingat bahwa efisiensi teknis yang dicapai oleh usaha peternakan berada pada daerah II yaitu rata-rata diatas 0,8. Namun secara teknis diharapkan bagi peternak agar dapat mengalokasikan inputinput produksinya lebih efisien lagi terutama dalam mengontrol penggunaan obat-obatan.

Karena sebagian besar peternak merupakan peternak kecil dengan tingkat keterampilan yang rendah, serta masih lemah dalam manajemen, sehingga pemerintah melalui dinas terkait perlu menyiapkan tenaga ahli/pendamping lapangan yang bisa membimbing peternak di Desa Bettet.

\section{DAFTAR PUSTAKA}

Debertin, DL. 1986. Agricultural Production Economics. MacMillan Publishing Company. New York.

Ellis, F. 1988. Peasant Economics : Farm Household and Agricultural Development. Cambridge University Press, Cambridge.

Gujarati, D. 1997. Ekonometrika Dasar. Penerbit Erlangga. Jakarta.

Gunawan, S dan Iswara. 1987. Teori Pengambilan Keputusan dalam Ekonomi Produksi. Penerbit Karunika. Universitas Terbuka. Jakarta.

Heady, E.O. 1952. Economics of Agricultural Production and Resources Use. Iowa States College. Prentice Hall,Inc., England Cliffts, New York. 439-638.

Henderson, JM dan Quandt. 1981. Microeconomic Theory : A Mathematical Approach. McGraw-Hill. New York.

Horne, J.C.V. 1983. Financial Management and Policy. Stanford University, Prentice Hall of India, 13-173; 182-210.

Mubyarto. 1977. Pengantar Ekonomi Pertanian, Edisi III. LP3S. Jakarta.

Nazir, M. 1989. Metode Penelitian. Ghalia Indonesia, Jakarta.

Semaoen, Iksan. 1992. Ekonomi Produksi Pertanian, Teori dan Apiikasi. Ikatan Sarjana Ekonomi Indonesia. Jakarta.

Singarimbun, Masri dan Sofian Effendi. 1995. Metode Penelitian Survey. LP3ES, Jakarta.

Soekartawi, et al. 1994. Teori Ekonomi Produksi dengan Pokok Bahasan Analisis Fungsi Cobb-Douglas. PT Raja Grafindo Persada. Jakarta. 